2. To: (Receiving Organization).

Distribution

5. Proj./Prog./Dept./Div.:

PFP Prog. Mgr.

8. Originator Remarks:

For approval and release.

11. Receiver Remarks:

11A. Design Baseline Document? $O$ Yes

No
4. Related EDT No.:

626775 thru 626783

7. Purchase Order No:

6. Design Authority/Design Agent/Cog. Engr.:

J.C. Sinclair, II I

$\mathrm{N} / \mathrm{A}$
9. Equip./Component No.:

$\mathrm{N} / \mathrm{A}$

10. System/Bldg./Facility:

$\mathrm{N} / \mathrm{A}$

12. Major Assm. Dwg. No.:

N/A

13. Permit/Permit Application No.:

N $/ \mathrm{A}$

14. Required Response Date:

$\mathrm{N} / \mathrm{A}$

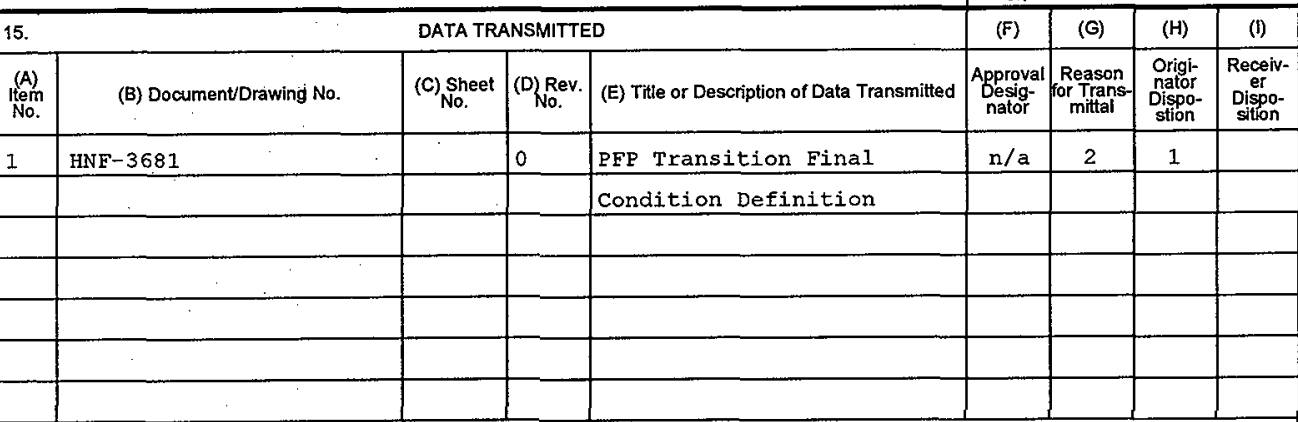

16.

KEY
Disposition (H) \& (I)

Approval Designator $(F)$ E, S, Q, D OR N/A Sec. 12.7)

1. Approval
2. Release
3. Information

17.

Reason for Transmittal (G)

4. Review

5. Post-Review

6. Dist. (Receipt Acknow. Required)

SIGNATURE/DISTRIBUTION

(See Approval Designator for required signatures)

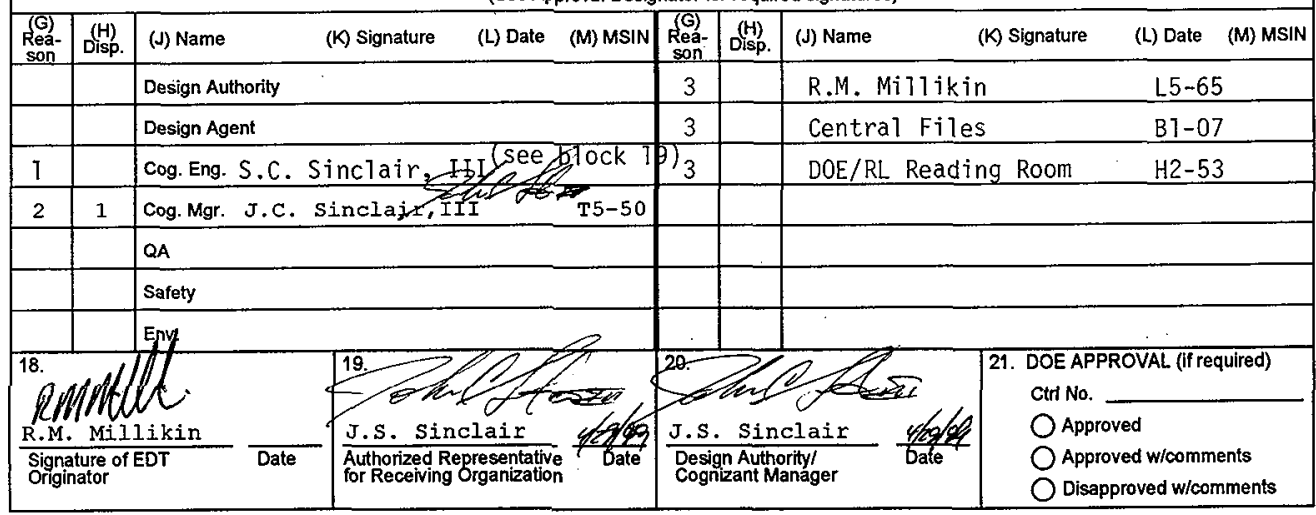




\title{
PFP Transition Final Condition Definition
}

\author{
J.C. Sinclair, III
}

B\&W Hanford Company

Richland, WA 99352

U.S. Department of Energy Contract DE-AC06-96RL13200

$\begin{array}{lll}\text { EDT/ECN: } & 626783 & \text { UC: } 2000 \\ \text { Org Code: } & 15000 & \text { Charge Code: } 103403 / \text { AROO } \\ \text { B\&R Code: } & \text { EW04J1050 } & \text { Total Pages: } 20 \% 11\end{array}$

Key Words: PEP, baseline, MYWP, transition, end point, final condition, deactivation, end state

Abstract: The purpose of this document is to describe the end state of the PFP Complex following completion of the PFP Stabilization and Deactivation Project. This document assumes that completion of DNESB 94-1 Recommendation material stabilization activities is a pre-condition for completion in a given area of PFP. The current planning case assumes that all above ground buildings and structures will be deactivated and dismantled to a clean "slab-on-grade."

TRADEMARK DISCLAIMER. Reference herein to any specific commercial product, process, or service by trade name, trademark, manufacturer, or otherwise, does not necessarily constitute or imply its endorsement, recommendation, or favoring by the United States Government or any agency thereof or its contractors or subcontractors.

Printed in the United States of America. To obtain copies of this document, contact: Document Control Services, P.O. Box 950, Mailstop H6-08, Richland WA 99352, Phone (509) 372-2420; Fax (509) 376-4989.
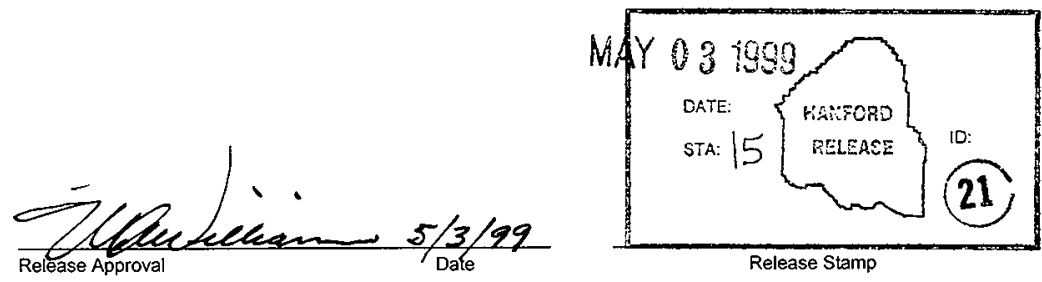

Release Stamp

\section{Approved For Public Release}




\section{PFP Transition Final Condition Definition}

HNF-3681, Rev. 0

Prepared by

B\&W Hanford Company and Fluor Daniel Hanford, Inc.

Prepared for

U.S. Department of Energy, Richland Operations Office 
Table of Contents

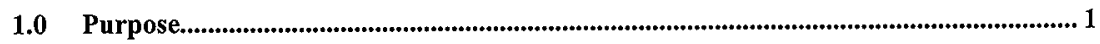

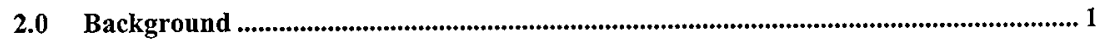

3.0 Mission and Performance Requirements.......................................................................... 2

4.0 PFP Final Condition Definition ........................................................................................... 3

5.0 Rationale for Final Condition .......................................................................................... 4

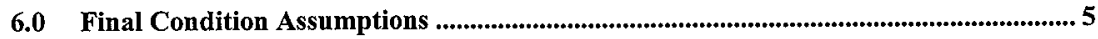

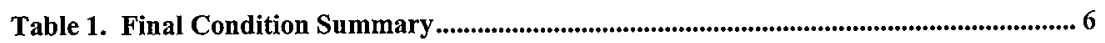




\subsection{Purpose}

The purpose of the PFP Transition Final Condition Definition is to describe the end state of the Plutonium Finishing Plant (PFP) Complex following completion of the PFP Stabilization and Deactivation Project. This document assumes that completion of the Defense Nuclear Facility Safety Board 94-1 Recommendation material stabilization activities is a pre-condition for completion of transition in a given area of PFP. The current planning case assumes that all above ground buildings and structures will be deactivated and dismantled to a clean "slab-ongrade" configuration prior to transition. It also assumes that all surface and below grade hazards will be deactivated to a "safe and stable" configuration, pending long-term surveillance and maintenance, and ultimate disposition. ${ }^{1}$

In addition to defining the final condition planned for the PFP Complex at transition, this document also addresses the bounding requirements and conditions that support, and in some cases drive, the final condition that must be achieved.

The final condition description provides a definitive definition that will be applied in detailed end point development for PFP transition and in subsequent detailed planning.

\subsection{Background}

The PFP is a Hazard Category II non-reactor nuclear facility that has been in use since the late 1940s. The complex contains chemical processing facilities, laboratories, storage vaults, support facilities, and offices to support plutonium storage and handling operations. The initial mission of PFP was the conversion of plutonium nitrate to plutonium metal and metal fabrication. The 234-5Z Building, the largest structure in the PFP Complex, was constructed to convert plutonium nitrate and subsequently plutonium oxide into plutonium metal. Follow-on missions for PFP included plutonium scrap recovery operations, reactor fuel manufacturing, and defense material processing. Safe storage of plutonium-bearing materials and new missions necessitated the construction of the $2736-Z$ Vault Complex.

In October 1996, the U.S. Department of Energy (DOE) issued a shutdown order for PFP processing operations. However, pending deactivation and dismantlement, PFP continues to store plutonium-bearing material, irradiated nuclear fuel, and other nuclear materials in a safe and compliant manner until these materials are dispositioned.

\footnotetext{
${ }^{1}$ An Environmental Impact Statement and Record of Decision has been issued under the National Environmental Policy Act of 1969 (NEPA) covering the majority of the proposed DNFSB 94-1 material stabilization activities at PFP. This existing Record of Decision also provides for the removal of readily retrievable Pu-bearing materials held-up in PFP systems and structures, by intrusive and destructive means, and the stabilization of those materials. Additional DOE programmatic NEPA documentation has been and is being prepared to address the consolidated storage and ultimate disposition of surplus plutonium and weapons-usable highly enriched uranium currently stored at many DOE facilities, including PFP. However, additional NEPA review will likely be required to address the proposed work scope for PFP deactivation and dismantlement to clean slab-on-grade.
} 
Unlike other nuclear facilities previously deactivated at Hanford (namely the former production reactors and the large, "canyon-type" reprocessing facilities), construction of the 234-5Z Building and many of the auxiliary facilities at PFP provides little long-term protection of the environment and public from residual materials and contamination. As a result, the project baseline as described in the Integrated Project Management Plan for the Plutonium Finishing Plant Stabilization and Deactivation Project, HNF-3617, Rev. 0, calls for stabilization and removal of plutonium-bearing material from the PFP Complex, deactivation of the PFP Complex, and dismantlement of above ground PFP structures to a clean "slab-on-grade" configuration within the next 20 years.

\subsection{Mission and Performance Requirements}

During the PFP transition activities, PFP will be required to comply with all applicable requirements governing ongoing surveillance and maintenance activities, special nuclear material management, radioactive material management, and facility deactivation. These requirements include, but are not limited to:

- Hanford Federal Facility Agreement and Consent Order (Tri-Party Agreement), Section 8.0 and associated milestones

- Conduct of Operations

- Environmental, Safety and Health

- Nuclear Safety

- Occupational Radiation Protection

- Quality Assurance

- Special nuclear material safeguards and security

- Facility Authorization Basis (i.e., Safety Analysis Report, Operational Safety Requirements), and implementing documents

- U.S. Department of Energy Orders and RL Implementing Directives

- Project Hanford Management Contract Policies, Procedures, Management Directives

- Site-wide and PFP facility-specific Standards/Requirements Identification Documents (S/RIDs).

The PFP transition activities and the end points that will be developed to complete deactivation and dismantlement of the PFP Complex are intended to eliminate, where possible, the conditions that result in a need for application of the requirements currently identified for PFP, and the subsequent implementation of those requirements. While transition of the PFP proceeds, a graded approach to requirement implementation will be applied, and a continual review of the applicability of requirements will be performed. This will enable PFP to eliminate, in a timely manner, requirements made unnecessary due to ongoing deactivation and dismantlement of systems, buildings, and structures. 


\subsection{PFP Final Condition Definition}

At the completion of the PFP Stabilization and Deactivation Project, each of the PFP Complex buildings and structures will have been transitioned to the final condition identified in Table 1.0. The final condition for each facility was determined based upon protecting the environment, the public, and the personnel who will perform the surveillances and maintenance activities at PFP during and following completion of transition activities. All actions to achieve the defined final conditions will be agreed to by EM-60, EM-40, and the state and federal regulators through development of end points for the project. This process will be in accordance with Tri-Party Agreement Section 8.0. The PFP Stabilization and Deactivation Project final conditions are defined as follows:

\subsection{Clean "Slab-on-Grade"}

A clean "slab-on-grade" is defined as a concrete slab (typically the first floor of a building) resting on grade (earth) in which the exposed surface has:

- All above-grade structures are removed.

- The portion of concrete slab that is exposed to the weather shall be free of dispersible radiological contamination.

- The traditional method of fixing contamination using conventional paint is not permissible.

- The exposed surface of the slab shall be free of tripping and puncture hazards.

- The exposed surface of the slab shall be suitable for exposure to the weather for at least 20 years.

- All penetrations through the slab shall be sealed with grout or equivalent suitable for exposure to the weather for 20 years.

- All wastes created as a function of the deactivation and dismantlement activities will be removed and disposed.

- As-left conditions shall be documented and stored retrievably.

\subsection{Safe and Stable}

All hazards, including those associated with waste sites, will be characterized, and:

- All surface and below grade hazards will be stabilized per the deactivation end points negotiated through the Tri-Party Agreement Section 8.0 end point process. The goal of such stabilization activities will be to place remaining surface and subsurface hazards in a condition that minimizes impacts to the environment.

- Where appropriate, subsurface radiological areas will be posted in accordance with applicable requirements.

- No surface soil contamination areas are allowed. Concrete caps and contamination fixatives are acceptable barriers.

- As-left conditions shall be documented and stored in a retrievable format and location consistent with previous projects (e.g., the Plutonium-Uranium Extraction Plant and B Plant). 


\subsection{Rationale for Final Condition}

The PFP Complex has several inherent risks to the safety and health of personnel, the public, and the environment. The risks that will be eliminated during the dismantlement of PFP include:

- Four metric tons of plutonium will be sent offsite for disposition

- $<100 \mathrm{kgs}$ of residual plutonium material holdup will be disposed of as transuranic waste

- Risk of criticality accidents will be eliminated

- Risk associated with unstable plutonium in storage and held up in facility equipment will be eliminated

- $172,000 \mathrm{~m}^{3}$ radioactive buildings cleaned and dismantled

- 7.2 hectares (17.8 acres) cleared and readied for environmental restoration

- Hanford's largest single point source for radiological dose due to air emissions (14.5\% of Hanford total in 1996) will be eliminated

- All man-made water discharges from PFP to soil column ended

- Risk of contamination spread due to surveillance and maintenance activities will be minimized and natural phenomena reduced to near zero.

Unlike the canyon facilities such as B Plant or the Plutonium-Uranium Extraction Plant, the PFP structure is not inherently robust. A canyon facility is typically a reinforced concrete structure with a thick-walled concrete canyon. A portion of the canyon is below grade. These structural features and the application of end points to establish the final condition of the facility clearly differentiate the durability of a canyon facility for an extended period of surveillance and maintenance from that of the braced steel-frame structure of PFP. Although sound, the steel building structure of many buildings in the PFP Complex, including 234-5Z Building, is subject to long-term deterioration without very costly maintenance.

While hazard assessments indicate that PFP would survive a $0.20 \% \mathrm{~g}$ earthquake, there would be significant damage, and the PFP Final Safety Analysis Report (FSAR) shows a significant plutonium release to the environment as a result.

In the event of an earthquake, the 232-Z Building would likely release a significant portion of the plutonium remaining in the building. Snow loading and roof drainage would be areas of concern for the 234-5Z Building if the building were left unheated (as it would be if it were deactivated in the fashion of a typical canyon facility). Snow loading in nearby Yakima County resulted in the collapse of approximately 50 industrial structures in the winter of 1996-1997. The buildings that collapsed were typically unheated warehouse type structures that experienced loading that was beyond code requirements. Although current administrative controls reduce the likelihood of exceeding design capacity, this type of beyond-design-code snow loading is credible at PFP. If the 234-5Z Building were left in an unheated condition, the snow loads could exceed capacity and result in roof damage or collapse, freeing trapped contamination.

Compounding these potential problems associated with deactivating PFP in the traditional fashion (i.e., without dismantlement), is the general porosity of the 234-5Z Building. The $234-5 Z$ is a steel structure with sheet metal siding. The joint between the floor slab and the walls is neither air nor water tight as are those of the canyon buildings. This joint, along with all the 
joints between the sheet metal panels and the gaps in the exterior doors, allow significant airflow into the building. Without constant controlled airflow, PFP would eventually lose contamination confinement control.

Numerous areas at PFP have contamination that has been fixed in place with paint. Many of these painted-over contamination areas are exposed to the weather. As a result of weathering, the paint can flake off, resulting in potential contamination spreads. In addition to the paintedover contamination, PFP has contamination that is not fixed but is trapped inside walls, ceilings, joints, etc. Occasionally, this trapped contamination migrates to exterior walls. Two notable examples of this are the exterior wall of room 152 of the 234-5Z Building and the southwest corner of the $232-Z$ Building.

Although 236-Z Building is considered a canyon type structure, the facility presents hazards similar to those of the other buildings in the PFP Complex in terms of seismic events and potential snow loading. Additionally, for 236-Z Building to remain standing following completion of transition activities, a new, stand-alone ventilation system would be necessary to maintain containment of radiological contamination that would remain.

To mitigate these conditions, the PFP currently has significant surveillance and maintenance activities ongoing to ensure that the physical systems, structures and radiological controls are in place. In addition, ongoing and proposed activities are completed in accordance with strict compliance to safety limits imposed by the facility safety analysis report. Maintaining a facility with this quantity of radiological material and contamination requires a significant annual investment of resources. Currently, these activities are estimated at approximately $\$ 50$ to $\$ 60$ million per year (excludes special nuclear material safeguards and security).

\subsection{Final Condition Assumptions}

Several assumptions are made in determining the applicable final configuration of the PFP Complex buildings, structures, and below grade hazards. Assumptions include:

- NEPA decision-making documentation will be prepared for the project and will determine that the safe and stable/clean "slab-on-grade" final condition is the preferred alternative.

- Soil remediation efforts will not be performed under the deactivation or dismantlement activities except as required to reach safe and stable transition end points.

- Waste disposal paths will be identified and available for all waste generated during deactivation and dismantlement activities.

- Leaving the PFP Complex above ground buildings and structures in place following transition presents unacceptable hazards due to aging/deterioration, seismic, and snow loading type events.

- Leaving 236-Z (PRF) Building in place following transition presents unacceptable hazards due to seismic and snow loading type events, and would require the construction of a new, stand-alone ventilation system to maintain contamination control. 
Table 1. Final Condition Summary

\begin{tabular}{|c|c|c|}
\hline Building, Facility, Waste Site & Description & Final Condition \\
\hline $216-Z-9$ & Crib & Safe and Stable \\
\hline $216-Z-9 A$ & Contaminated Soil Removal Building & Safe and Stable \\
\hline $216-Z-9 B$ & 216-Z-9 Mining Facility & Safe and Stable \\
\hline $216-Z-9 \mathrm{C}$ & 216-Z-9 Weather Enclosure & Safe and Stable \\
\hline $216-Z-1 D$ & $\begin{array}{l}\text { Backfilled Ditch (excluding those } \\
\text { portions of the ditch located outside the } \\
\text { PFP exclusion zone) }\end{array}$ & Safe and Stable \\
\hline $216-Z-13$ & Dry Well & Safe and Stable \\
\hline $216-Z-14$ & Dry Well & Safe and Stable \\
\hline $216-Z-15$ & Dry Well & Safe and Stable \\
\hline $225-\mathrm{WC}$ & Liquid Effluent Monitoring Station & Clean "Slab-on-Grade" \\
\hline $232-Z$ & PFP Incinerator Building & Clean "Slab-on-Grade" \\
\hline 234-ZB & Waste Material Storage Building & Clean "Slab-on-Grade" \\
\hline $234-\mathrm{ZC}$ & Waste Drum Storage Facility & Clean "Slab-on-Grade" \\
\hline $234-5 Z$ & Plutonium Finishing Plant & Clean "Slab-on-Grade" \\
\hline 234-5Z HWSA & Hazardous Waste Storage Area & Clean "Slab-on-Grade" \\
\hline $234-5 Z A$ & 234-5Z Change Room & Clean "Slab-on-Grade" \\
\hline $236-Z$ & Plutonium Reclamation Facility & Clean "Slab-on-Grade" \\
\hline $241-Z$ & Waste Storage and Treatment Facility & Clean "Slab-on-Grade" \\
\hline $241-\mathrm{ZA}$ & Waste Tank Sampling Building & Clean "Slab-on-Grade" \\
\hline $241-\mathrm{ZB}$ & Bulk Chemical Storage Tank & Clean "Slab-on-Grade" \\
\hline $241-\mathrm{ZG}$ & 241-Z Changeroom & Clean "Slab-on-Grade" \\
\hline 241-Z-RB & Retention Basins & Safe and Stable \\
\hline $241-Z-361$ & $\begin{array}{l}\text { Inactive Miscellaneous Underground } \\
\text { Storage Tank (IMUST) }\end{array}$ & Safe and Stable \\
\hline $242-Z$ & Waste Treatment Facility & Clean "Slab-on-Grade" \\
\hline $243-Z$ & Low-Level Waste Treatment Facility & Clean "Slab-on-Grade" \\
\hline 243-ZA & $\begin{array}{l}\text { Low Level Waste Treatment Storage } \\
\text { Tanks and Sump Pit }\end{array}$ & Clean "Slab-on-Grade" \\
\hline 243-ZB & Cooling Towers/Concrete Pad & Clean "Slab-on-Grade" \\
\hline $267-Z$ & Riser \#9 Valve House & Clean "Slab-on-Grade" \\
\hline $270-Z$ & Operations Support Offices & Clean "Slab-on-Grade" \\
\hline $291-Z$ & Ventilation Exhaust/Fanhouse & Clean "Slab-on-Grade" \\
\hline $291-Z-1$ & Main Exhaust Stack & Clean "Slab-on-Grade" \\
\hline 2607-WA & Septic Tank/Drainfield & Safe and Stable \\
\hline $2607-\mathrm{WB}$ & $\begin{array}{l}\text { Septic Tank/Drainfield. Transfer } \\
\text { ownership to DynCorp. }\end{array}$ & N/A \\
\hline $2607-Z$ & Septic Tank/Drainfield & Safe and Stable \\
\hline $2607-\mathrm{Zl}$ & Septic Tank/Drainfield & Safe and Stable \\
\hline $2607-\mathrm{Z} 8$ & $\begin{array}{l}\text { Septic Tank - does not exist. Submit } \\
\text { closure documentation }\end{array}$ & N/A \\
\hline $2701-\mathrm{ZA}$ & Patrol AMS/PFP & Clean "Slab-on-Grade" \\
\hline $2701-\mathrm{ZD}$ & PFP Badgehouse/Guard Station & Clean "Slab-on-Grade" \\
\hline $2702-Z$ & Communications Support Bldg. & Clean "Slab-on-Grade" \\
\hline
\end{tabular}




\begin{tabular}{|c|c|c|}
\hline Building, Facility, Waste Site & Description & Final Condition \\
\hline $2704-\bar{Z}-2$ & Safeguards/Security Offices & Clean "Slab-on-Grade" \\
\hline $2705-\bar{Z}$ & Operations Control Facility & Clean "Slab-on-Grade" \\
\hline $2712-\mathrm{Z}$ & Stack Monitoring Station & Clean "Slab-on-Grade" \\
\hline $2715-\mathrm{Z} / \mathrm{ZL}$ & Oil/Solvent Storage Building & Clean "Slab-on-Grade" \\
\hline $2721-Z$ & Emergency Generator Building & Clean "Slab-on-Grade" \\
\hline $2725-Z$ & Laundry Storage Building & Clean "Slab-on-Grade" \\
\hline $2727-\mathrm{Z}$ & Storage Building & Clean "Slab-on-Grade" \\
\hline $2729-Z$ & Storage Building & Clean "Slab-on-Grade" \\
\hline $2731-\bar{Z}$ & PR Can Storage Building & Clean "Slab-on-Grade" \\
\hline $2731-\mathrm{ZA}$ & Container Storage Building & Clean "Slab-on-Grade" \\
\hline $2734-Z$ & Gas Cylinder Storage Shed & Clean "Slab-on-Grade" \\
\hline $2734-\mathrm{ZA}$ & Gas Cylinder Storage Shed & Clean "Slab-on-Grade" \\
\hline $2734-Z \mathrm{~B}$ & Gas Cylinder Storage Shed & Clean "Slab-on-Grade" \\
\hline $2734-\mathrm{ZC}$ & Gas Cylinder Storage Shed & Clean "Slab-on-Grade" \\
\hline $2734-\mathrm{ZD}$ & Gas Cylinder Storage Shed & Clean "Slab-on-Grade" \\
\hline $2734-\overline{Z F}$ & Gas Cylinder Storage Shed & Clean "Slab-on-Grade" \\
\hline $2734-Z G$ & Gas Cylinder Storage Shed & Clean "Slab-on-Grade" \\
\hline $2734-\mathrm{ZH}$ & Gas Cylinder Storage Shed & Clean "Slab-on-Grade" \\
\hline $2734-\mathrm{ZJ}$ & Liquid Nitrogen Storage Pad and Tank & Clean "Slab-on-Grade" \\
\hline $2734-\mathrm{ZK}$ & Gas Cylinder Storage Shed & Clean "Slab-on-Grade" \\
\hline $2734-\mathrm{ZL}$ & Hydrogen Fluoride Facility & Clean "Slab-on-Grade" \\
\hline $2735-Z$ & Bulk Chemical Storage Tanks & Clean "Slab-on-Grade" \\
\hline $2736-Z$ & Long-term Vault Storage & Clean "Slab-on-Grade" \\
\hline $2736-\overline{Z A}$ & Z Vault Ventilation Building & Clean "Slab-on-Grade" \\
\hline $2736-\mathrm{ZB}$ & Plutonium Storage Vault Building & Clean "Slab-on-Grade" \\
\hline $2736-\mathrm{ZC}$ & Cargo Restraint Transport Dock & Clean "Slab-on-Grade" \\
\hline $2736-\mathrm{ZD}$ & Fuel Storage Cask Structure & Clean "Slab-on-Grade" \\
\hline $2902-Z$ & Elevated Water Storage Tank and Tower & Clean "Slab-on-Grade" \\
\hline $2904-\mathrm{ZA}$ & Liquid Effluent Monitoring Station & Clean "Slab-on-Grade" \\
\hline $2904-\mathrm{ZB}$ & Liquid Effluent Monitoring Station & Clean "Slab-on-Grade" \\
\hline Connex N-5 & Connex Boxes north of 234-5Z Building & Clean "SIab-on-Grade" \\
\hline Connex G\&E & Maintenance Connex Boxes & Clean "Slab-on-Grade" \\
\hline HS-043, HS-045 & Solid Waste Operations Connex Boxes & Clean "Slab-on-Grade" \\
\hline HS- 046, HS-047 & $\begin{array}{l}<90 \text { Day Waste Accumulation Area, } \\
\text { Connex Boxes }\end{array}$ & Clean "Slab-on-Grade" \\
\hline $\begin{array}{l}\text { M0-428, M0-432, M0-834, M0- } \\
889\end{array}$ & Mobile Offices & Clean "Slab-on-Grade" \\
\hline $200-W-58,200-W-59$ & $\begin{array}{l}\text { Z Plant Diversion Box } \# 1 \text { and } \# 2 \text {. } \\
\text { Transfer ownership to LMHC }\end{array}$ & N/A \\
\hline $\begin{array}{l}\text { UPR-200-W-23, UPR-200-W-74, } \\
\text { UPR-200-W-75, UPR-200-W-79, } \\
\text { UPR-200-W-89, UPR-200-W-90, } \\
\text { UPR-200-W-91, UPR-200-W- } \\
\text { 103, UPR-200-W-159 }\end{array}$ & Unplanned Release Sites & Safe and Stable \\
\hline Active Misc. Waste Stream 225 & $\begin{array}{l}234-5 Z C-H V A C \text { condensate drains } \\
\text { from roof }\end{array}$ & Safe and Stable \\
\hline Active Misc. Waste Stream 226 & $234-5 \mathrm{ZC}-\mathrm{HVAC}$ condensate drains & Safe and Stable \\
\hline
\end{tabular}




\begin{tabular}{|c|c|c|}
\hline Building, Facility, Waste Site & Description & Final Condition \\
\hline & from toof & \\
\hline Active Misc. Waste Stream 228 & $\begin{array}{l}234-5 Z-\text { Storm drain in stairwell to pipe } \\
\text { tunnel } \# 01\end{array}$ & Safe and Stable \\
\hline Active Misc. Waste Stream 229 & $\begin{array}{l}234-5 Z \text { - Storm drain in stairwell to pipe } \\
\text { tunnel } \# 04\end{array}$ & Safe and Stable \\
\hline Active Misc. Waste Stream 230 & $\begin{array}{l}234-5 Z \text { - Storm drain in stairwell to pipe } \\
\text { tunnel \#05 }\end{array}$ & Safe and Stable \\
\hline Active Misc. Waste Stream 231 & $\begin{array}{l}234-5 Z \text { - Storm drain in stairwell to pipe } \\
\text { tunnel } \# 06\end{array}$ & Safe and Stable \\
\hline Active Misc. Waste Stream 234 & $241 Z$ - Main steam line trap & Safe and Stable \\
\hline Active Misc. Waste Stream 235 & $241 Z$ - Waste tank steam supply trap & Safe and Stable \\
\hline Active Misc. Waste Stream 246 & $\begin{array}{l}\text { Ventilation condensate drain from duct } \\
\text { level }\end{array}$ & Safe and Stable \\
\hline Active Misc. Waste Stream 247 & $\begin{array}{l}\text { 234-5Z - PFP process support lab steam } \\
\text { trap }\end{array}$ & Safe and Stable \\
\hline Active Misc. Waste Stream 248 & 234-5Z main steam line trap $\# 01$ & Safe and Stable \\
\hline Active Misc. Waste Stream 249 & $234-5 Z$ main steam line trap $\# 02$ & Safe and Stable \\
\hline Active Misc. Waste Stream 250 & $234-5 Z$ main steam line trap $\# 03$ & Safe and Stable \\
\hline Active Misc. Waste Stream 254 & $\begin{array}{l}\text { 234-5Z - PFP complex main steam trap } \\
\# 01\end{array}$ & Safe and Stable \\
\hline Active Misc. Waste Stream 261 & $\begin{array}{l}216-Z-13 \text { ET- } 8 \text { fans and building } \\
\text { condensate }\end{array}$ & Safe and Stable \\
\hline Active Misc. Waste Stream 263 & $\begin{array}{l}216-Z-15 \text { ET- } 8 \text { fans and building } \\
\text { condensate }\end{array}$ & Safe and Stable \\
\hline Active Misc. Waste Stream 697 & $\begin{array}{l}234-5 Z-P F P \text { complex main steam line } \\
\text { trap } \# 02\end{array}$ & Safe and Stable \\
\hline Inactive Misc. Waste Stream 232 & 241-Z - Eyewash/safety shower & Safe and Stable \\
\hline Inactive Misc. Waste Stream 233 & $\begin{array}{l}241-Z-\text { Tank D-9 steam jacket } \\
\text { condensate }\end{array}$ & Safe and Stable \\
\hline Inactive Misc. Waste Stream 236 & 241-Z - Waste tanks steam supply trap & Safe and Stable \\
\hline Inactive Misc. Waste Stream 237 & $241-Z-$ Waste tanks steam supply trap & Safe and Stable \\
\hline Inactive Misc. Waste Stream 238 & $241-Z-$ Waste tanks steam supply trap & Safe and Stable \\
\hline Inactive Misc. Waste Stream 239 & $241-Z-$ Waste tanks steam supply trap & Safe and Stable \\
\hline Inactive Misc. Waste Stream 241 & 2736-Z - Complex main steam line trap & Safe and Stable \\
\hline Inactive Misc. Waste Stream 242 & 2734-ZL - Eyewash/safety shower & Safe and Stable \\
\hline Inactive Misc. Waste Stream 245 & $\begin{array}{l}232-Z-\text { Change room water heater } \\
\text { overflow }\end{array}$ & Safe and Stable \\
\hline Inactive Misc. Waste Stream 251 & $2902-\mathrm{Z}-$ High water tower steam trap & Safe and Stable \\
\hline Inactive Misc. Waste Stream 252 & 2704-Z - Main stream trap $\# 01$ & Safe and Stable \\
\hline Inactive Misc. Waste Stream 253 & 2704-Z - Main stream trap $\# 02$ & Safe and Stable \\
\hline Inactive Misc. Waste Stream 262 & 216-Z-14-Steam turbine condensate & Safe and Stable \\
\hline Inactive Misc. Waste Stream 587 & $\begin{array}{l}234-5 Z \text { - PFP complex main steam line } \\
\text { trap } \# 02\end{array}$ & Safe and Stable \\
\hline Inactive Misc. Waste Stream 654 & 2734-ZL - Emergency eyewash station & Safe and Stable \\
\hline Inactive Misc. Waste Stream 655 & $234-5 Z$ - Steam trap on $2902-Z$ high tank & Safe and Stable \\
\hline
\end{tabular}

